\title{
Study of Fish Diversity in Various Conditions of Water Level in Batu Bumbun Reservate of Middle Mahakam Regency of Kutai Kartanegara, East Kalimantan, Indonesia
}

Lariman", Sus Trimurti

Department of Biology Faculty of Mathematics and Natural Sciences, Mulawarman University, Jl. Barong Tongkok No. 4 Gn. Kelua. Samarinda, 75119 East Kalimantan, Indonesia

DOI: $10.36348 /$ sijcms.2020.v03i09.001

| Received: 12.10.2020 | Accepted: 25.10.2020 | Published: 05.11.2020

*Corresponding author: Lariman

\section{Abstract}

This study aims to determine the diversity of fish at various water levels in Batu Bumbun Reservat, as input material to formulate management activities that must be done to save the reserve. Research was carried out by survey method, in the dry season (April-June) and rainy season (November-December) 2016. Parameters measured, water quality (DO, pH, temperature, TSS, TDS, alkalinity and brightness), fish community structure diversity, uniformity, relative abundance, diversity and dominance), water levels, and sedimentation. The fish community data obtained were analyzed by the Shannon-Wiener index. The results showed that: (1) Changes in water level resulted in the Batu Bumbun Reservus ecosystem having experienced severe degradation, characterized by fluctuations in water level during two extreme seasons. When the rainy season occurs extreme floods, while the dry season, there is siltation to dry. (2) Community of fish caught in Batu Bumbun Reservus ecosystem of 29 species, consisting of 23 genus and 16 families. When the rainy season is dominantly caught fish community (white fish), with fish density 7.015 .000 head / $\mathrm{km} 2$, while the dominant season is dominant caught is a community of swamp (black fish), with density of 2,334,000 fish / $\mathrm{km} 2$. Based on the analysis of fish community, the value of diversity index $\left(\mathrm{H}^{\prime}\right)$ ranged from 1,188-0,825 means low-moderate species diversity, dominance index (C) around 0.0827-0.2147 means no dominant species and uniformity index (E) , 82950.6710 means that in a balanced state, there is no competition. It is concluded that the Batu Bumbun Reservus ecosystem has experienced severe degradation, with indicator of fish community change. It is recommended that the management must be done to save the Batu Bumbun Reservus ecosystem is, Dredging, Weed cleaning, Local Fish Restocking, illegal fishing Prevention, Increase of reservat security facility.

Keywords: Diversity of fish, Changes in water level, Batu Bumbun Reserves, Sedimentation.

Copyright (C) 2020 The Author(s): This is an open-access article distributed under the terms of the Creative Commons Attribution 4.0 International License (CC BY-NC 4.0) which permits unrestricted use, distribution, and reproduction in any medium for non-commercial use provided the original author and source are credited.

\section{INTRODUCTION}

In 1999 the Government of Kutai Regency with Perda No.3 Year 1999 concerning Regulation of Fishing in Regency Level II Region Kutai has set 11 lakes as fishery reserve / fishery, Eleven lakes that become fishery sanctuary are Lake Batu Bumbun, Loa Kang, Teluk Kademba , Berduit Bay, Selimau Bay, Ngayan, Lake Padam Api, Clay, Gab, Muntai River Bar, and Jantur Malang.

From the study of several agencies in 2004 (LIPI, Bapedalda Kukar and RASI) concluded that in Kutai Kartanegara only 2 fish reservates are functioning and the condition is very apprehensive, the two reserves are; (1) Batu Bumbun Reservation is located in Muara Muntai sub-district which is bordered on the bay (Ulak Banda) from Muara Tawar, Sungai Tawar and its surroundings to the Batu Bumbun Lake, from Muara Sungai Muntai, Labak Beto to Tanjung Kemujan, Keluang River and surrounding areas. The total area is about 450 ha; (2) Loa Kang Reservation is located in Kecamatan Kota Bangun which borders Kedang Kayu Bunga River to Mahakam river to Pela Lama and river that flows to Loa Kang Lake and its surrounding area + $750 \mathrm{Ha}$. The management of Batu Bumbun Reserves, and Loa Kang is an effort to plan, implement, monitor and evaluate fish resources conservation activities, utilization of fish resources and control of reservoir damage. Management of this reservoir to realize the creation of fish resources conservation [1].

Head of the Regional Environmental Impact Management Agency (Bapedalda) of Kutai Kartanegara Regency reported that deforestation has damaged the 
lake environment. "So, the nine lakes that are reserved in Kutai Kartanegara are lost because their boundaries, such as trees or grasses, are no longer existed, and the existence of lakes around the Mahakam River is increasingly threatened by the permission to open dozens of plantation projects large-scale palm oil around the lake area "There are at least 26 oil palm plantation projects licensed for clearing land around Bangun Town." Additionally, the granting of mining permits in the Gunung Bayan area upstream of the Mahakam River is also increasingly threatening the existence of the main lakes in the upper Mahakam River, including the reservat lake [2].

The ecosystem destruction of the fish reservat area has resulted in the decreasing fishery potential. In the 1970s the average catch of fish each year from Lake Semayang and Melintang reaches 25,000 to 35,000 tons. In 1993, the average fishing catches from Semayang and Melintang Lakes were 5,139.7 tons / year, even in 2004 the average catch rate was only 750 tons / year [3].

Damage to the physical and chemical environments as well as the excessive exploitation of fishery resources from a waters will also affect the pattern of distribution and density of fish in it. Data in many waters indicates that population degradation has led to a reduction in production due to over-fishing [4]. Research on the aspects of fish eco- logology covering community structure and the factors of the condition of each fish species should be done as basic information for the conservation activities of fish resources and other organisms whose lives depend on fish resources. This study is also useful as inputs in fisheries management efforts to ensure the sustainability of the supply of these fish for the livelihood of fishermen [5].

Batu Bumbun Reserves (Muara Muntai, Kukar, East Kalimantan) have important meaning as a source of livelihood, and feeding ground Pesut Mahakam (Orcaella brevirostris). Increased community activity and unfriendly fishing are alleged to have suppressed the existence of fish populations that affect the catches of fishermen and the decline in population Pesut which is a fish-eating mammal.

\section{MATERIALS AND METHODS}

Research was conducted by survey method, in the dry season (April-June) and rainy season (November-December) 2016. Parameters measured, water quality (DO, $\mathrm{pH}$, temperature, TSS, TDS, alkalinity and brightness), fish community structure diversity, uniformity, relative abundance, diversity and dominance), water levels, and sedimentation. The fish community data obtained were analyzed by the Shannon-Wiener index.

The reason for choosing the location of this research is because Reservat Batu Bumbun is a spawning place of fish which become source of feed of Pesut Mahakam (Orcaella brevirostris) in Mahakam River. According to Kreb [6], Pesut's main habitat is located in the middle of the Mahakam River, including Muara Muntai and Danau Semayang Rivers. Furthermore, it was also identified that there are two sub-populations of Pesut namely in Muara Pahu, Kedang Rantau River and Pela River.

The research equipment used is GPS, digital SLR camera with minimum lens $300 \mathrm{~mm}$ to record the image of fish sample, identification book and water quality measurement equipment that is Water Quality Checker-Horiba U-10. Water quality parameters such as temperature, $\mathrm{pH}$, Dissolved oxygen = DO, Turbidity and Conductivity are measured directly in the field randomly for each location of observation.

Fish samples obtained by taking all types of fish caught by fishermen in Batu Bumbun Reservation area and Batu Bumbun River. The fish samples were then taken to the laboratory to be identified using the Kotelat, Saanin and Weber \& Beaufort books 7-9].

\section{RESULTS AND DISCUSSION}

Batu Bumbun Reservation which is the location of this research is located in Muara Muntai Subdistrict Kutai Kartanegara Regency of East Kalimantan Province at geographic position $116^{\circ} 31$ 'East Longitude-116 $33^{\circ}$ East Longitude and between $0^{\circ} 18$ 'South Latitude - $0^{\circ} 45^{\prime}$ South Latitude. Batu Bumbun Reservation when designated as a fishery sanctuary by King Kutai called Kenohan Aji has an area of $450 \mathrm{Ha}$, but from time to time in line with the increase of community activities according to the Department of Fisheries Resort Muara Muntai this reserve has been reduced to $300 \mathrm{Ha}$. Where initially Lake Laran, Ridan lake, and Lake Tawar to the freshwater into reserves Batu Bumbun area, but according to the Department of Fisheries Branch Muara Muntai with high community activity and land transfer function then the area above is not included in the reserve area Batu Bumbun. With the absence of Lake Laran, Ridan lake, and Freshwater to the fresh river into the reserve area of Batu Bumbun then reserves Batu Bumbun has shrinkage up to $33.3 \%$ [10].

In line with the higher human activity around it, the Batu Bumbun reserve is undergoing a very drastic change, the impact of deforestation as a result of which many erosions and mud are carried by the flood that goes into the reservoir which then reserves Batu Bumbun undergoes siltation. Then the impact of long drought the vegetation reservat Batu Bumbun which is a water plant many die drought. The impact of overfishing / fishing activities using fishing gear (trawling and stun) by fishermen from outside the village resulted in many extinct fish species, plus the management of reserves by the Fisheries and Marine Offices are not optimal, the final impact is the current 
Batu Bumbun reserve / fishery sanctuary as protection of the spawning area, fish farming and rearing are not working properly and the reservat conditions are changing [10].

\section{Batu Bumbun Reservat conditions during the rainy season / flood}

At the time of the rainy season, the reservoir of Batu Bumbun becomes a flooded puddle where its entire area $(300 \mathrm{Ha})$ is inundated with water entering from various directions, the water is brownish white (cloudy) because it contains a lot of mud (Figure-1). During the rainy season / flood the stagnant water in the reservoir soaks all the surrounding weeds, the old water is inundated so that it becomes clear, but due to soaking the weeds long enough the weeds eventually decay then the water changes color to brown, smelly, low $\mathrm{pH}$ and oxygen levels decreased, water conditions like this are often known as the water bangai / bangar. Rizal [11] explains that Bangar water is one of the natural phenomena that occurred since the first in the waters of the Mahakam River and is an ecological disaster that occurs every year in the Mahakam River. The phenomenon of water bangar occurs at the turn of the season between the dry season to rainy season and vice versa. The change of seasons leads to changes in some significant water quality parameters such as low oxygen dissolved in water (DO), low $\mathrm{pH}$, high $\mathrm{H} 2 \mathrm{~S}$, high levels of ammonia and other water quality parameters in Mahakam River waters that can not be tolerated by fish , this is what resulted in the fish that pass water flow bangai / bangar this many died suddenly.

The phenomenon of water bangar there are two kinds, first occurs during floods, water bangar is water that has been in the catchment areas of water, lakes and swamps. Where in it is overgrown by plants during the dry season. After that the area of the lake or swamp is submerged in water during the rainy season. Plants in the area eventually died and decomposed, due to submerged water. When there is a process of decomposition in plants in the lake or swamp, come the rainy season on the upper course of the Mahakam River which resulted in the water contained in lakes and swamps pushed out into the flow of the Mahakam River. The exit water is blackish brown and smells of drunken or floating aquatic fish such as baung and shrimp. The two aerial water that occurs during the dry season, where the water reaches the lowest level so that the water with low $\mathrm{pH}$ and $\mathrm{DO}$ at the bottom of the waters stirred up the surface. The water is dark brown, smells stingy, with low $\mathrm{pH}$ and $\mathrm{DO}$ resulting in death of aquatic biota [12].

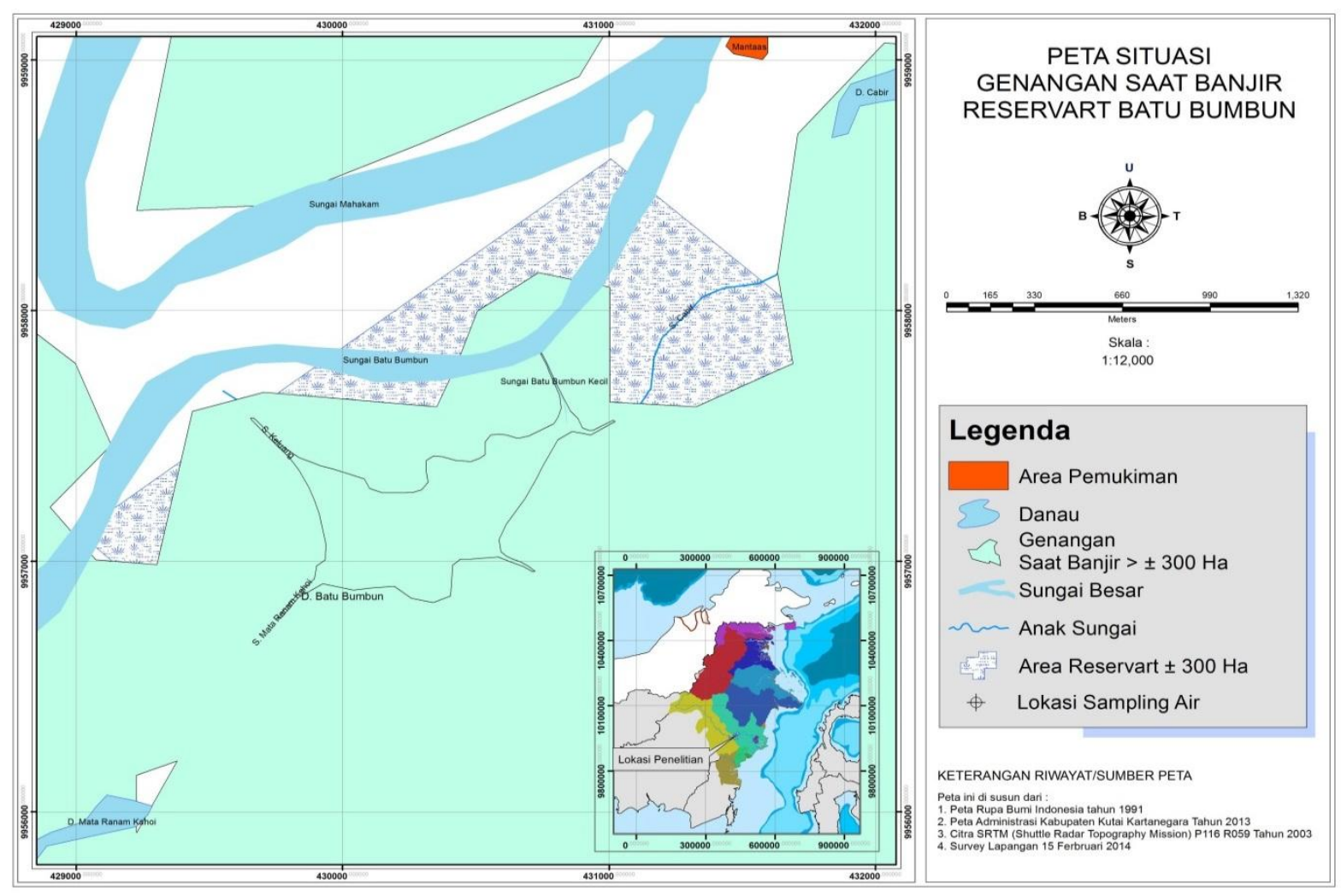

Fig-1: Map of pond pool situation of Batu Bumbun Resrvat during flood

\section{Batu Bumbun Reservat conditions at normal time}

At the time of normal condition of reservoir area of Batu Bumbun which flooded about $50 \mathrm{Ha}$ (Figure-2), this condition happened during rainy season and no flood occurred, in this condition according to Ibrahim reservat can function optimally, clear water, water depth reach 3- $4 \mathrm{~m}$, the fish can be spawn and well developed characterized by the high diversity of 
fish species, at which time various species of putihan fish can be found in the Batu Bumbun reserve. But conditions like the above can only be found before the 1990 s, in the past 25 years is very rare to find the natural ideal conditions as before. While Mas'ud and
Eta (fishermen) said before the 1990s Muara Muntai community, Muara Wis, and Kota Bangun very easy to find fish, do not take long and sophisticated tools enough with nets and gill nets have a lot of fish.

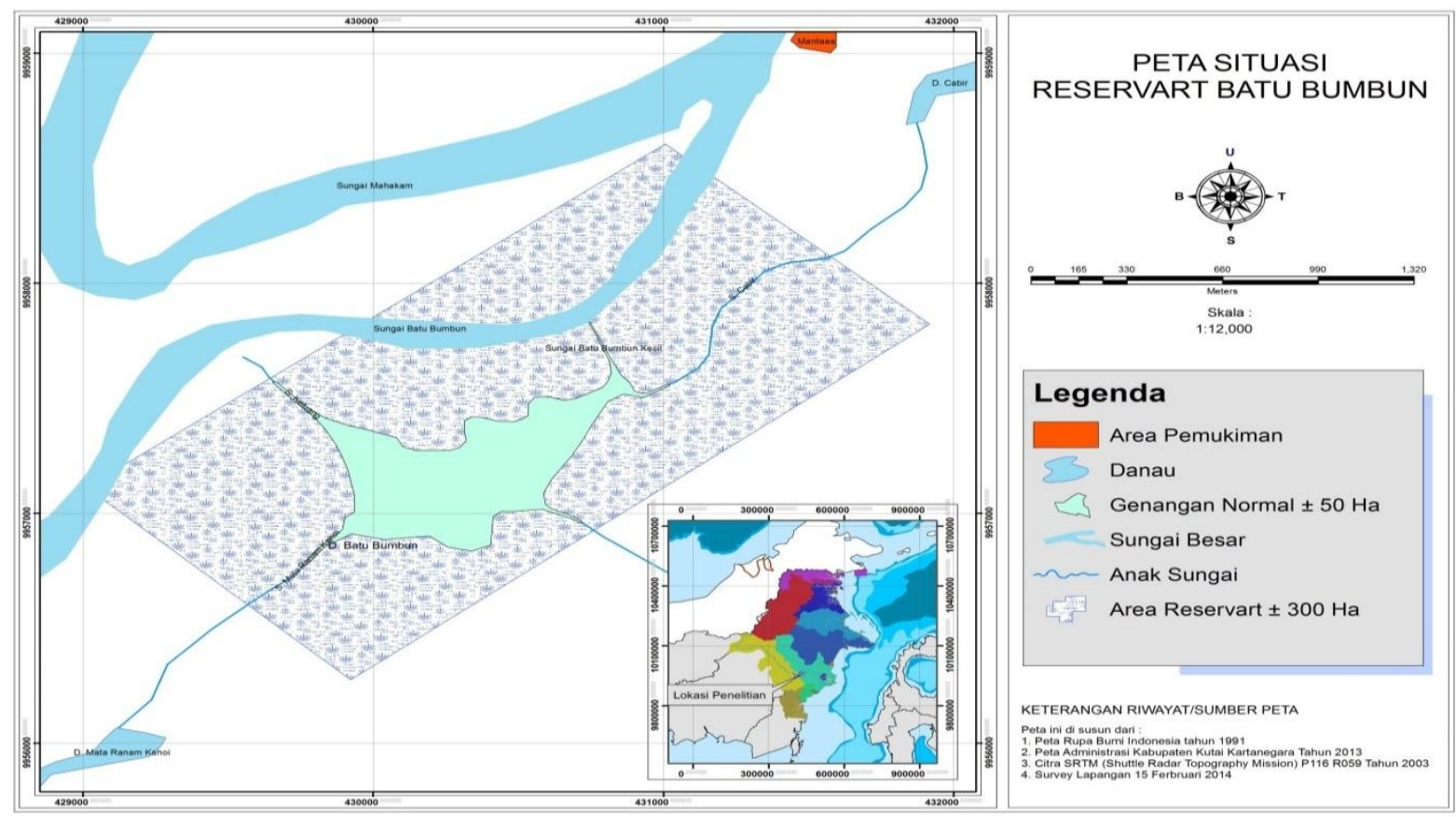

Fig-2: Map of pond pool situation of Batu Bumbun reservat during normal condition

Batu Bumbun Reservat conditions during the dry season

After the 1990s, according to Bapak Ibrahim the condition of Batu Bumbun reserves experienced a very drastic change, ranging from the loss of vegetation diversity, the loss of small streams of water inlet to reservat, siltation, the decrease of reservoir water and the decline of fish species diversity, fish community.
During the dry season (Figure 3 and 4) The reservoir area of Batu Bumbun that is inundated only about 2.5 ha, even if the long dry season the reserved area which is water and can be a fish sanctuary is only about $0.75 \mathrm{Ha}$ so that must be made kumpaian or rumpon from water hyacinth. In conditions such as above water depths of only about $45 \mathrm{~cm}$ and fish communities can be found only species of swamp fish, such as fish, biawan fish and cork fish.

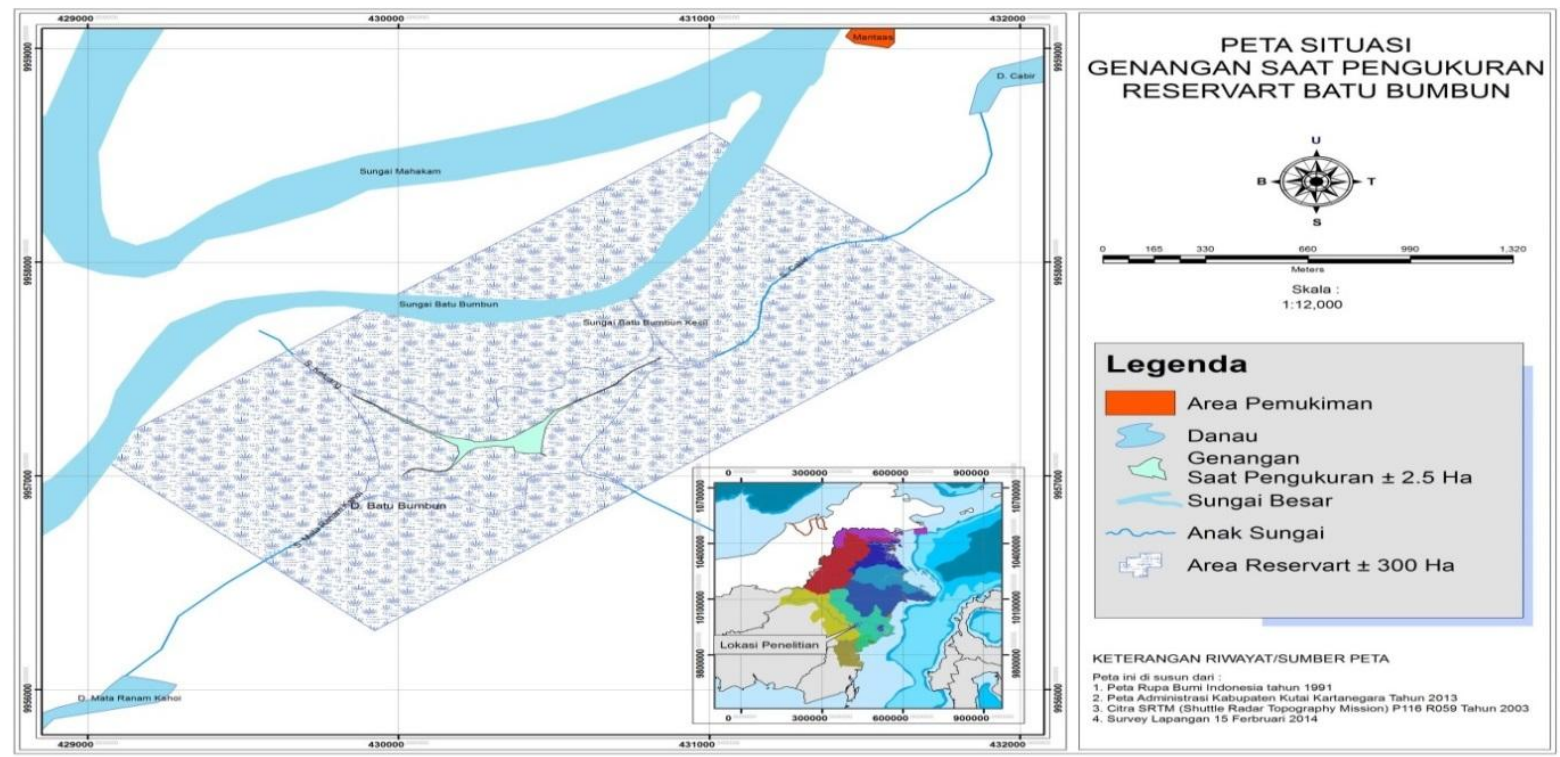

Fig-3: Map of pond pool situation of Batu Bumbun reservat at low tide condition 


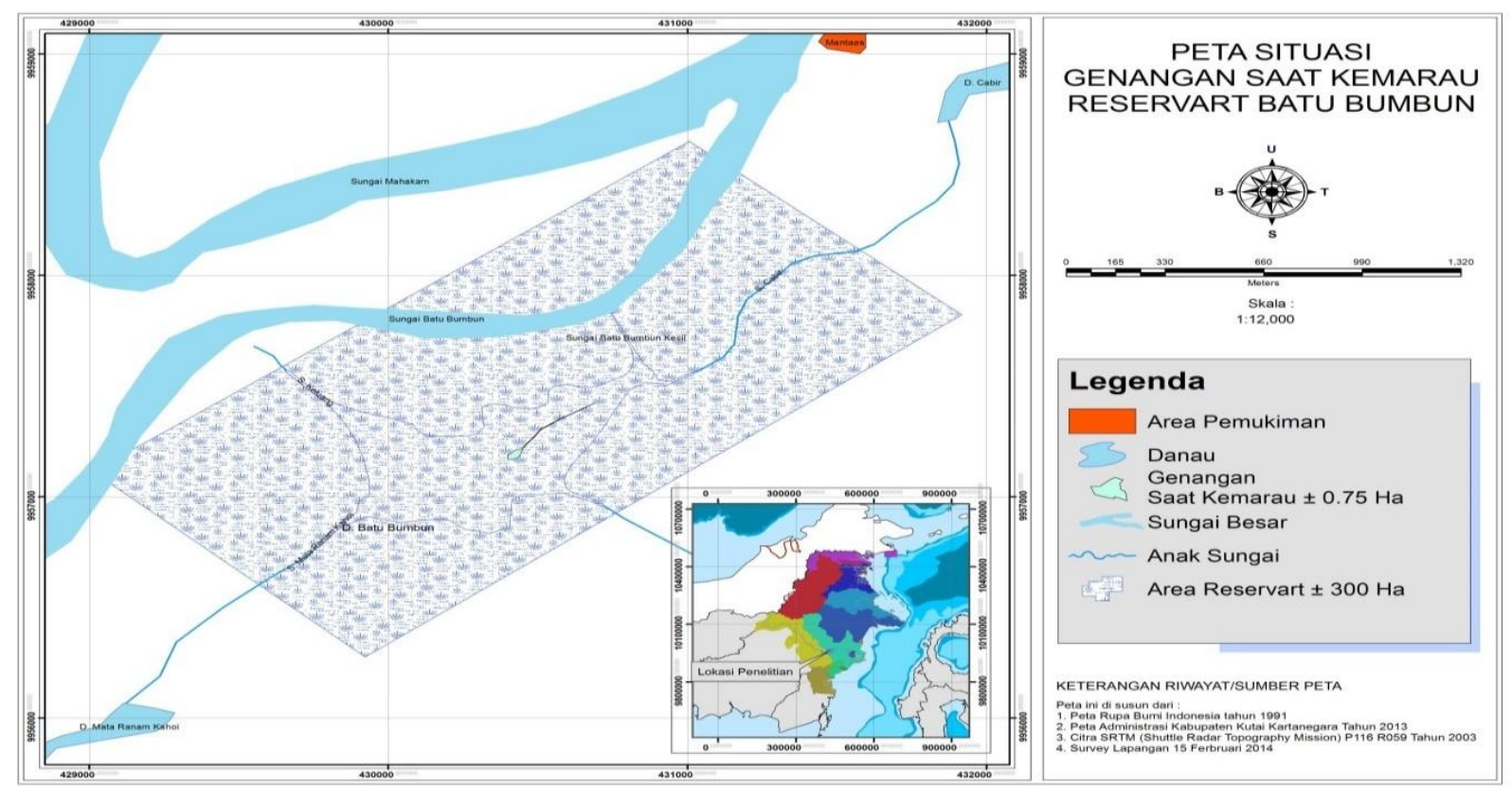

Fig-4: Map of pond pool situation of Batu Bumbun reservat during shallow condition

\section{Water Level Front Expectation Data}

As floodplain-type waters, the Batu Bumbun Lake is characterized by seasonal fluctuations in water as a result of flooded Tawar, Keluang and Mahakam rivers. At the time of the flood season, reserves of Batu Bumbun characterize large stagnant waters, while at low tide some areas of the lake into a stretch that is not watery. These periods of flooding of these waters will create the major habitat or habitat varieties that vary based on the saturation level of the water in the soil substrate: i) the territorial waters, that is, areas that are permanently inundated or flowing waters; ii) Wetland areas, experiencing flooding within a period of almost $75 \%$ of their annual pattern ( 9 months); iii) Territory of saturated land, experiencing flooding $50 \%$ of its annual pattern (6 months); iv) The area of moist land, experiencing flooding $25 \%$ of the annual pattern (3 months); v) Dry land (land), ie non-inundated areas [13].

Geomorphological conditions are crucial to the sub-typology of habitats, related to the flow patterns of each habitat with the main channel at the time the water conditions recede. Based on these geomorphological conditions will create sub typology: i) Open water, both flowing river and stagnant waters of the lake; ii) Closed waters are characterized by the separation of these waters temporarily from their main waters at low tide, these waters are among the backswamps [14].

Changes in water fluctuations, and sedimentation can be a major problem in the fisheries sector in the future if there is no anticipation of prevention and mitigation from now on. The accumulation of the above problems began to be felt by the fishing communities in particular, with the tendency of decreasing catches in recent years due to the destruction of Batu Bumbun reserves so that it can not become a fishery sanctuary, although the truth is questionable because it is likely that fishermen do not take into account the catch fish that they use to feed the pet fish in the karamba [15].

While the rapid receding time with longer dry periods no longer corresponds to the lifecycle order that must be lived. For example, the dryness of water basins known to the community as "lakes" in the dry season is largely misinterpreted as a result of the high sedimentation rate which causes the depth of the lake to decrease. Though the phenomenon of drought is more caused by the absence of water input and the rate of water receding is greater in a longer period. "Lake" or "zone" that is too fast to dry causing mass mortality of fish without a chance to be utilized by fishermen around the lake. Changes in water fluctuations are also suspected to alter the vegetation structure that grows in the waters of the lake [16].

An important factor that shapes the character of the flood lake is the fluctuation of the lake's water level, due to the high fluctuations in the water level which play a major role in stimulating the high level of biological productivity in the lake waters. However, in line with changes in land use in the upstream catchment area, the annual fluctuation pattern of the annual water level changes marked the more extreme differences in fluctuations in maximum and minimum water levels [13].

The results of the fluctuations of lake waterfront data analysis during the last 24 years (19892012) from the Kalimantan River Basin III - Kaltim Region, the Ministry of Public Works show that the maximum annual water level varied the lowest in 2003 
at 24.88 and the highest in 2007 at 29.94. Maximum water level was relatively stable in the period 19892002 and subsequent periods of fluctuation (Figure 4.9).
This sharper fluctuation pattern also occurs for the minimum annual water level during the data recording period (1989-2012).

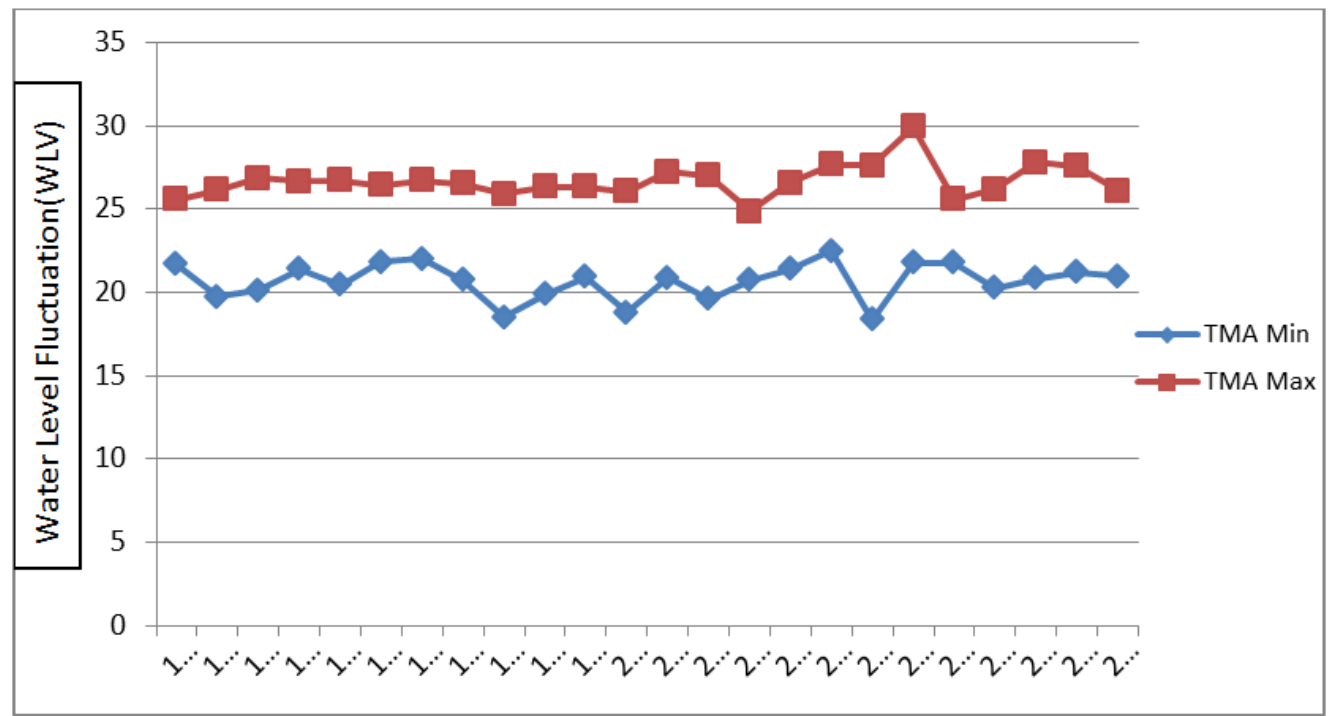

Fig-5: Annual Water Level Front Fluctuation (TMA) at Kotabangun Station

From the picture of fluctuations in the yearly water level above can also be seen the data of the condition of the extreme low tide level occurred in 1997, 2000 and year 2006, respectively showing the numbers 18,48, 18,78 and 18,37 AWLR levels. This extreme lake fluctuation pattern is adversely affecting the function of lake waters as a habitat, where flood disasters are likely to wipe out existing habitat resources, while rapid receding times with longer dry periods are no longer in accordance with the life cycle order of fish that must be lived.

\section{Batu Bumbun Reservate Water Quality}

In general, water quality in Batu Bumbun reservat waters is still quite good. The measurement of water fertility index that shows the condition of moderate - high fertility level is suspected to be the nature of the lake waters of flood exposure, because the input of organic material internally from water bodies due to the degradation of plants when the water is inundated.

The character of reservoir water of Batu Bumbun is strongly influenced by its input water, where the water entering from Sungai Tawar and Sungai Keluang tends to be acidic (peat water) while water from Mahakam River is more neutral.

Table-1: Water Quality Data of Batu Bumbun Reservate

\begin{tabular}{|l|l|l|l|l|l|l|}
\hline No & Parameter & \multirow{2}{*}{ Unit } & \multicolumn{2}{l|}{ Condition } \\
\cline { 5 - 8 } & & & Flood Water & Normal Water & Low tide & Shallow Water \\
\hline A. & Water physics & & & & & \\
\hline & Air temperature & oC & 30 & 30 & 31 & 31 \\
\hline 2. & Water temperature & oC & 28 & 28 & 28 & 29 \\
\hline 3. & Brightness & $\mathrm{Cm}$ & 30 & 50 & 60 & 45 \\
\hline 4. & Dissolved Solids & $\mathrm{mg} / \mathrm{lt}$ & 33 & 16 & 12 & 9 \\
\hline 5. & Suspended solids & $\mathrm{mg} / \mathrm{lt}$ & 189 & 38 & 25 & 20 \\
\hline B. & Chemistry & & & & & \\
\hline 6. & pH & & 6,8 & 6,9 & 5,8 & 5,6 \\
\hline 7. & Dissolved oxygen & $\mathrm{mg} / \mathrm{lt}$ & 5,4 & 6,3 & 2,6 & 2,5 \\
\hline 8. & Alkalinity & $\mathrm{mg} / \mathrm{lt}$ & 18,96 & 19,50 & 27,54 & 16,50 \\
\hline 9. & Hardness & $\mathrm{mg} / \mathrm{lt}$ & 6,10 & 4,20 & 4,0 & 3,40 \\
\hline
\end{tabular}

The result of measurement of several parameters of aquatic environment which is estimated to affect the distribution and abundance of fish communities in the Batu Bumbun reserve area ecosystem is shown in Table-1. Based on the measurement of insitu using waterchecker, the water quality parameters are all still in optimal condition for fish to grow and develop. 


\section{Fish Community in Batu Bumbun Reservate}

According to Odum [17] the study of the biota community is the basis of the overall ecosystem assessment it is necessary to conduct research to determine the structure of fish communities based on diversity, relative abundance, dominance, and uniformity. Based on existing data to date there has been no research on water quality in the Batu Bumbun reserve and its relation to the community structure of fish caught in the reserve. Fish species of fish community constituents that can be captured in the Batu Bumbun reserve are 29 species and can be seen in Table-2. Data on the number of fish species obtained is greater than that of Nasution [18] number of fish species caught during the dry season (April and June 2006) and the rainy season (November 2006) using the experimental gillnet every four hours for 24 hours on the Muara Kaman River are 19 species, whereas in Lake Semayang there are 24 species of fish, this is understandable because the research site is a reservoir is a breeding ground for various species of fish. But smaller than reported for the Mahakam River by Purnomo [14], and in Semayang Lake and Melintang [15]. The smaller number of species is due to sampling of fish in this study based solely on catches using experimental gill net and nets.

Table-2: Fish species caught with gill nets and nets in Batu Bumbun Reservat area

\begin{tabular}{|c|c|c|c|c|c|c|c|}
\hline \multirow[t]{2}{*}{ No } & \multirow[t]{2}{*}{ Regional Name } & \multirow[t]{2}{*}{ Regional Name } & \multicolumn{4}{|c|}{ Condition } & \multirow{2}{*}{$\begin{array}{l}\text { Ind } \\
\end{array}$} \\
\hline & & & Flood & Normal & Low tide & shallow & \\
\hline 1. & Kendia & Thynichthyes vaillanti & 276 & 315 & - & - & 591 \\
\hline 2. & Repang & Osteochilus repang & 235 & 253 & - & - & 488 \\
\hline 3. & Jelawat & Leptobarbus vaevenie & 78 & 98 & 3 & - & 179 \\
\hline 4. & Baung & Macrones microchantus & 23 & 53 & 3 & - & 79 \\
\hline 5. & Puyau & Osteochilus hasselti & 78 & 102 & 7 & 1 & 188 \\
\hline 6. & Salap & Puntius schwanefeldi & 53 & 178 & - & - & 136 \\
\hline 7. & Senggiringan & Macrones nigriceps & 25 & 135 & 17 & - & 177 \\
\hline 8. & Bentilap & Criptopterua apogon & 12 & 37 & - & - & 49 \\
\hline 9. & Berukung & Barbichtyes leavis & - & 35 & - & 3 & 38 \\
\hline 10. & Lais & Belodontichyes dinema & 17 & 78 & - & - & 95 \\
\hline 11. & Lalang & Nematabramis everetti & 44 & 78 & 5 & 3 & 130 \\
\hline 12. & Seluang & Chela oxygastroides & 53 & 235 & 75 & 13 & 376 \\
\hline 13. & Belida & Chitala lopis & 2 & 12 & 5 & - & 19 \\
\hline 14. & Lancang & Pangasius micronema & 3 & 14 & - & - & 17 \\
\hline 15. & Lepok & Ompok sabanus & 6 & 25 & 11 & - & 42 \\
\hline 16. & Kesili & Macrognathus aculeatus & - & 4 & 7 & 2 & 13 \\
\hline 17. & Gabus & Channa striatus & 2 & 17 & 23 & 8 & 50 \\
\hline 18. & Toman & Channa micropeltes & - & 13 & 17 & 5 & 35 \\
\hline 19. & Biawan & Helostoma temmincki & 23 & 53 & 256 & 113 & 445 \\
\hline 20. & Tempe & Polycanthus hasselti & 7 & 15 & 25 & 15 & 62 \\
\hline 21. & Sepat rawa & Trichogaster trichopterus & 17 & 153 & 235 & 215 & 620 \\
\hline 22. & Belunguran & Stenogobius geninttatus & - & - & 15 & 23 & 38 \\
\hline 23 & Susur Batang & Homaloptera wassinki & - & - & 15 & 17 & 32 \\
\hline 24 & Betutu & Oxyeleotris marmorata & - & 3 & 25 & - & 28 \\
\hline 25 & Sepat siam & Trichogaster pectoralis & 15 & 135 & 205 & 198 & 553 \\
\hline 26 & Pepuyu & Anabas testudineus & - & 12 & 67 & 32 & 111 \\
\hline 27 & Lele akar & Clarias nieuhofii & - & 5 & 18 & 21 & 44 \\
\hline 28 & Lele dumbo & Clarias gariepinus & - & 2 & 11 & 15 & 28 \\
\hline 29 & Nila & Oreochromis niloticus & - & 5 & 7 & 3 & 15 \\
\hline
\end{tabular}

It was found that the composition of fish communities in reserved waters of Batu Bumbun at the time of flood water and normal water (rainy season) is different from the composition of fish communities during low tide and shallow water (dry season), when the flood water and normal water composition of ikhtiofauna reservat Batu Bumbun is dominated by members of the Cyprinidae tribe. The dominance of the Cyprinidae tribe is common in tropical waters of Indonesia [19-21]. However at low tide the composition of ikhtiofauna reservat species of Bumbun Stone is dominated by members of the Helostomidae tribe and when shallow water is dominated by members of the Osphronemidae tribe.

The result of analysis of fish community structure covering dominance index, species diversity, and uniformity index. The result of analysis of fish community structure data (Table-3) shows that ecologically there is temporal difference of temporal values between rain season (flood) and dry season. 
Table-3: Diversity index value $\left(\mathrm{H}^{\prime}\right)$, dominance index $(\mathrm{C})$ and uniformity index $(\mathrm{E})$ fish in the waters Batu Bumbun Reservat

\begin{tabular}{|l|l|l|l|l|}
\hline No & Condition & H' & C & E \\
\hline 1 & Flood & 0,961 & 0,164 & 0,8295 \\
\hline 2 & Normal & 1,188 & 0,082777 & 0,7202 \\
\hline 3 & Low tide & 0,964 & 0,15968 & 0,7202 \\
\hline 4 & Shallow & 0,825 & 0,214172 & 0,6710 \\
\hline
\end{tabular}

The value of diversity index $(\mathrm{H}$ ') ranged from 1.188 to 0.825 where the highest value is in the condition of normal reservoir water is 1.188 , while the lowest value is in shallow reservoir water condition is 0.825 . The value of dominance index $(\mathrm{C})$ ranges from $0.08277-0.214172$, where the highest value is in shallow reservoir water condition is 0.214172 , while the lowest value is in the condition of normal reservoir water that is 0,082777 . The value of uniformity index (E) ranged from $0.8295-0.6710$, the highest uniformity value is in the condition of flood reservoir water that is 0.8295 , while the lowest value is in shallow reservoir water condition that is 0.6077 .

\section{Diversity Index}

The value of diversity index $(\mathrm{H}$ ') ranged from 1.188 to 0.825 where the highest value is in the condition of normal reservoir water is 1.188 , while the lowest value is in shallow reservoir water condition is 0.825 .

Based on the criterion of Shanon-Weiner (in Odum, 1993) that When $\mathrm{H}$ '<1: Low diversity, $1<\mathrm{H}^{\prime}$ $<3$ : Medium diversity and $H^{\prime}<3$ : High diversity. The value of diversity index $\left(\mathrm{H}^{\prime}\right)$ in the condition of normal reservoir water 1,188 , indicates that reservoir waters of Batu Bumbun during normal water condition have diversity of species which are classified as moderate with medium individual distribution. Meanwhile, when the condition of reservoir water flood, reservoir water condition receded and shallow water reservat condition value of diversity index $H^{\prime}<1$, it means that in all three conditions above reservat have diversity of species which is classified as low.

Index of diversity and dominance is used to determine the effect of environmental quality on fish larvae community. The effect of environmental quality on fish abundance varies greatly depending on fish species, as each fish species has different adaptations and tolerances to its habitat. The index is used to obtain more detailed information about the fish community [22]. In principle, the index value is higher, meaning the waters community is more diverse and not dominated by one or more of the existing taxon.

The main factors affecting the number of organisms, species diversity and dominance include the destruction of natural habitats such as land conversion, chemical and organic pollution, and climate change [23].

\section{Index of Dominance}

The value of dominance index $(\mathrm{C})$ ranges from $0.08277-0.214172$, where the highest value is in shallow reservoir water condition is 0.214172 , while the lowest value is in the condition of normal reservoir water that is 0,082777 . Simpson [24] suggests that if the index value of dominance is close to zero means no dominance and if the value of the dominance index is close to one then there is a species that appears in the waters. Based on the dominance index value ranges from $0.08277-0.214172$, it can be said that the diversity of species of Batu Bumbun reservat waters is still good because no species are dominant in the fish community.

Many of the few species present in a water sample will affect the index of dominance, although this value is highly dependent on the number of individuals of each species [25].

The effect of environmental quality on fish abundance varies greatly depending on fish species, as each fish species has different adaptations and tolerances to its habitat. The index is used to obtain more detailed information about the fish community [22].

\section{Uniformity Index}

The uniformity index describes whether the distribution of individual numbers of each species is obtained uniformly or not. The uniformity index is the composition of each individual in a species present in a community. The uniformity index (E) is a good predictor of determining dominance in an area. Levinton [26] describes when one or more species are abundant from others, the uniformity index will be low. Jonathan [27] states that if the index value of uniformity exceeds 0.7 indicates the degree of uniformity of the community is high

The uniformity index value $(\mathrm{E})$ of the research results is $0.8295-0.6710$. The highest uniformity value is in the condition of flood reservoir water that is 0.8295 , while the lowest value is in shallow reservoir water condition that is 0,6077 .

According to Odum [24], if $\mathrm{E}$ is $<0.5$ or near 0 means that the uniformity of organism species in the waters is unbalanced, where there is competition in both space and food. Based on the criteria of Odum [24] the uniformity of fish species in reservoir waters of Batu Bumbun 0.8295 - 0.6710 included in a balanced state. Thus there is no competition either on the place (space) or food in the waters reservat Batu Bumbun.

As Wilhm [28] points out, the greater the value of uniformity denotes high species uniformity, ie the abundance of species can be said to be the same and the tendency to be dominated by certain species is very small. 


\section{Batu Bumbun Reservate Sedimentation}

The lakes in Medle Mahakam include Batu Bumbun Reservate classified as flood lake. The personal communication about the Batu Bumbun reserve inundation is spoken by Ibrahim (reservoir keeper) especially in the dry season is too shallow and in the rainy season becomes very deep (flood). The reservoir water comes from the overflow of Tawar River, Keluang River and Mahakam River is strongly influenced by rainfall. Therefore, in addition to the shallow fluctuations in the water level, it is also possible as a result of forest clearance by logging or conversion of forest into agricultural land in catchment areas such as forest concessions (HPH and HTI), mining (coal and gold), and plantations.

At present, reserve conditions of Batu Bumbun along with their respective catchments have been seriously degraded and problematic. This is particularly characterized by the occurrence of silting which results in a decrease in the quantity and quality of water, some of which are thought to originate from the degradation of the land contained in each of the upstream DTAs. The degradation mechanisms of such land can be in the form of soil material present in areas of eroded clearing and transported by strong rainforest forces. The eroded soil material becomes a source of sediment material, which then accumulates both in river channels and is recovered. The problem is not separated from the influence of human activities and natural disasters, which can lead to the opening of the land surface. The opening of this land is mainly suspected by the existence of human activities, namely in the form of logging or land use which is not in accordance with the allocation, which in whole this activity is less or not pay attention / care for soil and water conservation. Meanwhile, natural disasters such as large scale forest and land fires also spur land clearing and increased soil erosion rates, all of which will be a potential source of sediment material for the sedimentation rate of Batu Bumbun Reservate .

Fahrudin et al., [29] describes the results of the study that sedimentation rates in the lakes of the Mahakam River watershed, especially in the rainy season are very high, reaching $2,338 \mathrm{mg} / \mathrm{sec}$ in Semayang lake and $6.488 \mathrm{mg} / \mathrm{sec}$ in Melintang lake. Sediments from upstream of the Mahakam watershed are the main sedimentary sources that enter the waters of the lake through the Mahakam river, reaching up to $90 \%$ of the overall sedimentation process that occurs. Based on the analysis of grain characteristics of sediment, it is known that most of the sediment material is clay to galuh (silt). This composition is thought to be related to relatively sloping topography of river basin and relatively slow water flow rate so as not to be able to carry large grain-sized sediments far from erosion sources in the upper reaches.
According to Mislan [30] that As a sedentary sedimentary ecosystem, the wetlands of MMA tend to face increasing sediment and shallow rates. Prior to 1985 during the dry season Reservus Batu Bumbun still has a depth of about $2 \mathrm{~m}$, the longer the shallow and since 2010 during the dry season dry Bumbun Stone reserve (does not serve as a reservat), so if averaged each year the reserved sendimentation of about $8 \mathrm{~cm}$, if this phenomenon is not immediately overcome (done dredging) then sedimentation rate in the next few years accumulation of this sediment stimulates the growth of water vegetation, and can make the Batu Bumbun reserve lost to the mainland.

\section{CONCLUSION}

Based on the result of study of biophysical condition of Batu Bumbun reserve area ecosystem, community and management strategy, it can be concluded:

1. Pond Bumbun reserve area ecosystem has experienced severe degradation, leading to critical condition. At the time of high rainfall, and Mahakam river water level reaches maximum (11 $\mathrm{m})$, flood occurs, and during the dry season, Mahakam river water level reaches a minimum $(4.5 \mathrm{~m})$ then reservoir water drops, until drought.

2. Species Fish caught during research in the ecosystem of Batu Bumbun reservat area of 29 species. When water reservoirs are flooded and reservoir water is normal, catching fish species are dominated by fish whitish communities (white fish), while at low tide the dominant community of black fish is caught.

3. As a sedentary sedimentary ecosystem, the area of Mahakam Tengah lake tends to face increasing sediment and shallow rates. Based on the analysis of grain characteristics of sediment, it is known that most of the sediment material is clay to galuh (silt). This composition is thought to be related to relatively sloping topography of river basin and relatively slow water flow rate so as not to be able to carry large grain-sized sediments far from erosion sources in the upper reaches.

\section{REFERENCE}

1. Manning, N., Barma, N., Blondel, J., Pilichowski, E., \& Wright, V. Anonymous.(1999). Strategic Decisionmaking in Cabinet Government. Washington DC: World Bank.

2. Sayekti, A. A. S. (2004). Faktor-Faktor yang Mempengaruhi Permintaan Beberapa Bahan Pangan Penting dalam Pola Konsumsi Pangan Rumah Tangga di Indonesia.

3. Jeneberang, B. P. D. A. S. Walanae. 2010 Laporan hasil kegiatan fasilitasi penyusunan rencana kerja hutan desa.Direktorat Jenderal Rehabilitasi Lahan dan Perhutanan Sosial. Jakarta.

4. Effendie, M. I. (1979). Metoda biologi perikanan. Yayasan Dewi Sri. Cetakan I, Bogor. 112 hlm.

5. Nasution, S. H., Hartoto, D. I., Dharmadi, \& Oktaviani, D. (2008). Kelimpahan ikan 
Putihan dan hubungannya dengan pemunculan Pesut Mahakam. Jurnal Oseanologi dan Limnologi Di Indonesia, 34(2):133-149.

6. Kreb, D. (2004). Facultative river dolphins. Conservation and social ecology of freshwater and coastal Irrawaddy dolphins in Indonesia. Copyright@ D. Kreb 2004: 230.

7. Weber, M., \& de Beaufort, L. F. (1913). The fishes of the Indo-Australian Archipelago, II: Malacopterygii. Myctophoidea, Ostariophysi, 1 .

8. Weber, M. W. C., \& de Beaufort, L. F. (1916). The Fishes of the Indo-Australian Archipelago.. (Vol. 3). EJ Brill Limited.

9. Weber, M., \& de Beaufort, L. F. (1922). The Fishes of the Indo-Australian Archipelago: Heteromi, Solenichthyes, Synentognathi, Percesoces, Labyrinthici, Microcyprini (Vol. 4). EJ Brill Limited.

10. Christin, N. (2013, May). Traveling the Silk Road: A measurement analysis of a large anonymous online marketplace. In Proceedings of the 22nd international conference on World Wide Web (pp. 213-224).

11. Rizal, C. S. (2007). Study of magnetic anisotropy and magnetoresistance effects in ferromagnetic $\mathrm{Co} / \mathrm{Au}$ multilayer films prepared by oblique incidence evaporation method. Journal of Magnetism and Magnetic Materials, 310(2), e646e648.

12. Zellner, S. N., Enzmann, M. J., \& Moton Jr, R. T. (2004). U.S. Patent No. 6,738,808. Washington, DC: U.S. Patent and Trademark Office.

13. Mislan, A., Elmore, D., Hatten, L., \& Dacho, Q. (2004). A Multi-Level And Multivariate Data Recovery System Of Hydroinformatics In An Estuarine Environment Using Anns. In Proceedings of the 6th International Conference on Hydroinformatics: Singapore, 2124 June 2004 (Vol. 2, p. 1377). World Scientific.

14. Purnomo, K. (1994). Potensi sumberdaya perikanan di Danau Semayang dan Melintang. Frontir. Universitas Mulawarman. Samarinda, 14:123-136.

15. Lukman \& Gunawan. (1998). Lake Semayang and Melintang, East Kalimantan as the habitat of Freshwater Dolphin. Dalam: Anonimus (Eds). Pendayagunaan dan Rehabilitasi Lingkungan Perairan Danau Semayang Kalimantan Timur, Puslitbang Ekonomi dan Pembangunan LIPI, Jakarta. Hal. 51-68.

16. Sharma, M., \& Branscum, P. (2010). EDITORIAL Is Alcoholics Anonymous Effective?. Journal of Alcohol \& Drug Education, 54(3), 3.

17. Odum, H. T. (1996). Environmental accounting: emergy and environmental decision making (Vol.
707). New York: Wiley.

18. Nasution, S. H., Hartoto, D. I., Dharmadi, \& Oktaviani, D. (2006). (In publication). Struktur komunitas dan kelimpahan fitoplankton di lingkungan habitat Pesut Mahakam. 16 hal. (Dalam proses penerbitan di Jurnal Penelitian Perikanan Indonesia).

19. Doi, A. R., Komatsu, \& Hartoto, D. I. (2000). Fish occurring in a black water oxbow lake in South Borneo. Report of the Suwa Hydrobiological Station Shinshu University. No.12:25-28.

20. Hartoto, D. I. (2000). An overview of some limnological parameters and management status of fishery reserves in Central Kalimantan. Report of the Suwa Hydrobiological Station Shinshu University No.12:49-74.

21. Hartoto, D. I., \& Mulyana, E. (1996). Hubungan antara parameter kualitas air dan struktur ikhtiofauna perairan darat Pulau Siberut. The relationship of water quality parameter and inland water Ichthyofauna Structure of Siberut Island. Oseanologi dan Limnologi di Indonesia (OLDI), No. 29:41-55.

22. Anwar, J., \& Zahn, D. (2011). Uncovering molecular processes in crystal nucleation and growth by using molecular simulation. Angewandte Chemie International Edition, 50(9), 1996-2013.

23. Widodo, A. (1997). An autonomously distributed traffic flow simulator including inter-vehicle communications. IEICE Technical Report.

24. Odum, W. E., Odum, E. P., \& Odum, H. T. (1995). Nature's pulsing paradigm. Estuaries, 18(4), 547.

25. Kaswadji, R. F. (1976). Studi Pendahuluan Tentang Penyebaran dan Kelimpahan Phytoplankton di Delta Upang, Sumatera Selatan. Karya Ilmiah Fakultas Perikanan IPB Bogor. Bogor.

26. Levinton, J. S. (1982). Marine ecology. New Jersey: Prentice-Hall.

27. Hodgkin, J., Horvitz, H. R., \& Brenner, S. (1979). Nondisjunction mutants of the nematode Caenorhabditis elegans. Genetics, 91(1), 67-94.

28. Wilhm, J. L. (1975). Biological indicators of pollution. River ecology. Studies in ecology., 2.

29. Fahrudin, A. (2012). Pengantar kesejahteraan sosial. PT Refika Aditama.

30. Mislan, K. A. S., \& Babcock, R. C. (2008). Survival and behaviour of juvenile red rock lobster, Jasus edwardsii, on rocky reefs with varying predation pressure and habitat complexity. Marine and Freshwater Research, 59(3), 246-253. 